\title{
Ameliorative Roles of Exogenous Testosterone on Nitrite Damaged Testes and Sperm Parameters
}

\author{
Wasiu O. Akintunde ${ }^{*}$, Kehinde T. Adenowo², Kehinde A. Ojo², Abdulrahman Ab- \\ dulfatai 1
}

\author{
${ }^{1}$ Department of Anatomy and Cell Biology, Ladoke Akintola University of Technology, Ogbo- \\ moso, Nigeria \\ ${ }^{2}$ Department of Anatomy and Cell Biology, Olabisi Onabanjo University, Ago-Iwoye, Nigeria
}

\author{
*Correspondence should be addressed to Wasiu O. Akintunde: owakintunde@lautech.edu.ng \\ Received 23 July 2019; Revised 04 October 2019; Accepted o9 October 2019
}

\begin{abstract}
(C) 2019 Akintunde et al. Licensee Pan African Jourmal of Life Sciences. This is an Open Access article distributed under the terms of the Creative commons Attribution License (https://creativecommons.org/licenses/BY/4.o), which permits unrestricted use, distribution, and reproduction in any medium, provided the original work is properly cited.
\end{abstract}

Background: Nitrate $\left(\mathrm{NO}_{3}\right)$ is a common food additive used as a colour fixation and preservative in meats and fish. Human dietary exposure to $\mathrm{NO}_{2}$ is mostly through the inter-conversion of $\mathrm{NO}_{3}$ from vegetables, cured meat products, fresh meat, fish, dairy products, eggs and water intake. This experiment was designed to investigate to what extent exogenous testosterone $(\mathrm{T})$ ameliorates the destructive effects of nitrite $\left(\mathrm{NO}_{2}\right)$ on rats' testes and sperm parameters.

Methods: Thirty-five adult male Wistar rats weighed between $100 \mathrm{~g}-111 \mathrm{~g}$ was used for the experiment. Rats were divided into 7 groups, for each group $n=5$. Group $A$ received distilled water, group $B_{1} C_{1}$ and $D_{1}$ received o.04mg/ $\mathrm{kgbw}, 0.06 \mathrm{mg} / \mathrm{kgbw}$ and $0.08 \mathrm{mg} / \mathrm{kgbw}$ of $\mathrm{NO}_{2}$ respectively in total volume of $1 \mathrm{ml}$ distilled water for 60 days. Groups $\mathrm{B}_{2}, \mathrm{C}_{2}$ and $\mathrm{D}_{2}$ also received $0.04 \mathrm{mg} / \mathrm{kgbw}, 0.06 \mathrm{mg} / \mathrm{kgbw}$ and $0.08 \mathrm{mg} / \mathrm{kgbw}$ of $\mathrm{NO}_{2}$ respectively followed by intramuscular injection of testosterone (Andriol Testocaps) at $5 \mathrm{mg} / \mathrm{kgbw}, 7.5 \mathrm{mg} / \mathrm{kgbw}$ and $10 \mathrm{mg} / \mathrm{kgbw}$ respectively every other day for 3 weeks

Results: The quality of testicular cells was implicated by oral administration of $\mathrm{NO}_{2}$; distorted or deformed seminiferous tubules with loss of germinal cells were evident. Meanwhile, the $\mathrm{NO}_{2} / \mathrm{T}$-treated testes showed normal tubular structures with complete spermatogenesis except at high dose of $0.08 \mathrm{mg}$ which showed mild vacuolation and arrested spermatogenesis. Consequently, the sperm counts was reduced significantly $(\mathrm{P}>0.05)$ following increased $\mathrm{NO}_{2}$ concentrations. However, the sperm counts of $\mathrm{NO}_{2} / \mathrm{T}$-treated testes were statistically increased $(\mathrm{P}<0.05)$ at dose dependent manner. The number of motile sperms of the testes exposed to $\mathrm{NO}_{2}$ was decreased insignificantly, meanwhile, $\mathrm{NO}_{2} / \mathrm{T}$-treated-testes were found to be increased insignificantly $(\mathrm{P}>0.05)$.

Conclusion: The reactive oxygen species triggered by $\mathrm{NO}_{2}$ generated testicular oxidative stress, spermatogenesis disruption and histological damages within the period of 60 days of ingestion. Meanwhile, these possible toxicological effects caused by $\mathrm{NO}_{2}$ could be effectively reversed using androgen hormone (testosterone) therapy within the period tested according to the present study.

Keywords: Nitrite, Testosterone, Rats, Testes, Spermatozoa 


\section{1.o INTRODUCTION}

Nitrate causes health hazard when it is converted to nitrite. Once nitrate is ingested, its conversion to nitrite takes place in human saliva of all ages, and in the gastrointestinal tract of infants. Infants convert approximately double or $10 \%$ of ingested nitrate to nitrite compared to $5 \%$ conversion in older children and adults. However, emphasis has not been made on how its conversion could possibly affects body system. Other sources of $\mathrm{NaNO}_{2}$ are various industries including agricultural, chemical, textile processing, disinfectants and colouring industry. Humans are constantly exposed to $\mathrm{NaNO}_{2}$ through food and water intake, with minor contribution from air $[1,4]$.

The common forms of nitrogen in water are nitrate, nitrite, ammonia and organic nitrogen (as might be found in plant matter). Nitrites gain access to water through the use of corrosion inhibitors in industrial process, or through the conversion from ammonia or nitrates. Nitrites can also be introduced into a water body when human or animal sewage are broken down by bacteria in the environment or from chemically fertilized land through runoff. Nitrites can be consumed directly, or formed after the conversion of nitrates to nitrites in the stomach. Babies under six months of age are particularly susceptible to hazard of nitrite, which leads to symptoms such as shortness of breath, a blue colour around the mouth referred to as Blue Baby Syndrome (methemoglobinemia), cyanosis and these could finally lead to death at a very high level of nitrites exposur $[2,3]$.

Sodium nitrite $\left(\mathrm{NaNO}_{2}\right)$ is an inorganic salt with various industrial applications. In blood circulation, $\mathrm{NaNO}_{2}$ oxidizes hemoglobin to methemoglobin which is incapable of transporting oxygen and can cause hemichypoxia (insufficient oxygen). Recent studies have shown that hypoxia affects testicular functions[5]. Longterm exposure to high levels of nitrites in adults can result in increased urine production since nitrites are diuretic [6]. Insufficient oxygen or hypoxia has also been reported to produce a great physiological stress which induces cellular response that results in deleterious effects on certain tissues $[7,8]$. This has been shown to have an impact on male testicular functions such as reduction of testosterone level [9] and disturbances of spermatogenesis [10]. For instance, hypobaric hypoxia which is associated with high altitude exposure to nitrite is reported to induce a state of oligoasthenospermia with reduced motility, a reduction of the total number of motile sperms and an increase in abnormal or immature spermatozoa [11,12].

Testosterone is a hormone made by animal body and is responsible for the normal growth and development of male sex organs and for maintenance of other sexual characteristics. Specifically, it is produced in the testis, the male reproductive organ that also produce sperm, The functions of testosterone include growth and maturation of prostate and other male sex organs, changes in body muscle mass and strength and fat distribution, sex drive, mood and sexual function, energy level, bone strength and it is necessary for normal sperm development [13]. It also activates genes in sertoli cells, which promote differentiation of spermatogonia and maturation and fertility of spermatozoa [14].

Exogenous testosterone has been shown to maintain or suppress testicular function in a variety of species, depending upon the dosage and has been used theoretically but empirically in the attempts to maintain or increase libido [15]. Other authors have reported that exogenous testosterone increase the concentration of testosterone in plasma obtained from whole-body samples of blood after decapitation. It was noted that a daily dosage of nearly $2 \mathrm{mg}$ of testosterone was required to elevate concentration of testosterone in plasma above normal in Japanese quail $[16,17]$.This experiment was therefore designed to investigate to what extent exogenous testosterone ( $\mathrm{T}$ ) ameliorates the destructive effects of nitrite $\left(\mathrm{NO}_{2}\right)$ on rats' testes and sperm parameters.

\subsection{METHODOLOGY}

\subsection{Chemicals}

Nitrite $\left(\mathrm{NO}_{2}\right)$ Salt (dissolved in distilled water by preparing stock/mother solution) and Testosterone (Andriol Testocaps) were obtained from Sigma-Aldrish, Germany. All other chemicals were of analytical grade.

\subsection{Animals and Treatment}

The rats were procured from the breeding stock of the Anatomy Department of Ladoke Akintola University of Technology, Ogbomoso. All the rats were maintained on a standard rat chow obtained from Ladokun feeds and concentrate, Ibadan and portable water was provided for them. The experiment involved 35 adult male Wistar rats weighed between $100 \mathrm{~g}$ - 111g. The rats were divided into 7 groups, for each group $n=5$. Group A (control), received $1 \mathrm{ml}$ distilled water, group $\mathrm{B}_{1}, \mathrm{C}_{1}$ and $\mathrm{D}_{1}$ received $0.04 \mathrm{mg} /$ $\mathrm{kgbw}, \quad 0.06 \mathrm{mg} / \mathrm{kgbw}$ and $0.08 \mathrm{mg} / \mathrm{kgbw}$ of $\mathrm{NO} 2$ respectively in total volume of $1 \mathrm{ml}$ distilled water for 60 days. Groups $\mathrm{B}_{2}, \mathrm{C}_{2}$ and $\mathrm{D}_{2}$ also received $0.04 \mathrm{mg} / \mathrm{kgbw}$, $0.06 \mathrm{mg} / \mathrm{kgbw}$ and $0.08 \mathrm{mg} / \mathrm{kgbw}$ of $\mathrm{NO}_{2}$ respectively for 60 days followed by the intramuscular injection of 
testosterone (Andriol Testocaps) at 5mg/kgbw, 7.5mg/ $\mathrm{kgbw}$ and $10 \mathrm{mg} / \mathrm{kgbw}$ respectively every other day for 3 weeks.

\subsection{Analyses}

The rats were sacrificed by dislocation of their cervical bones not less than four hours after the last dosing of both substances. The epididymides were removed for semen analysis (sperm parameters), and testes were also removed for testicular oxidative status and preserved in Bouin's fluid for routing qualitative analyses of the testes

\subsection{Statistical analysis}

Data were expressed as Mean \pm S.E.M. A two way analysis of variance (ANOVA) was employed in analyzing the data. Duncan's multiple range t-tests was carried out to determine statistical significance between treatment means at 95\% confidence level. The tests were considered statistically significant when $\mathrm{P}<0.05$. The software was Prism Graphpad, 2009 edition .

\subsection{RESULTS}

\subsection{Histological Features}

Histological findings in the control group depicted a normal cytoarchitecture of rat testes showing a normal shape and arrangement of seminiferous tubule with intact basement membrane and progressive proliferation of spermatogenic cells capable of producing matured spermatozoa (Figures 1). Group $\mathrm{B}_{1}$ showed distorted seminiferous tubule with broken basement membrane (Figure 2). Group $\mathrm{C}_{1}$ treated rats showed impaired spermatogenesis due to degeneration of spermatogenic cells, seminiferous tubules with abnormal shape, distorted region of tubules and wide interstitial space (Figure 3). Group $\mathrm{D}_{1}$ showed seminiferous tubule with deformed or irregular shape, wide lumen without spermatogenesis, and no germ cells (Figure 4). However, after administration of testosterone the rats in Group $B_{2}$ was shown to have normal seminiferous tubule with normal germ cells layer and spermatogonia cells with full maturation for spermatozoa production (Figures 2). Rats in group $\mathrm{C}_{2}$ showed normal shape and arrangement of seminiferous tubule with intact basement membrane and progressive proliferation of spermatogenic cells to produce matured spermatozoa (Figure 3). Group $\mathrm{D}_{2}$ showed seminiferous tubules with several vacuolations and maturation arrest with some inadequate germinal cells (Figure 4).

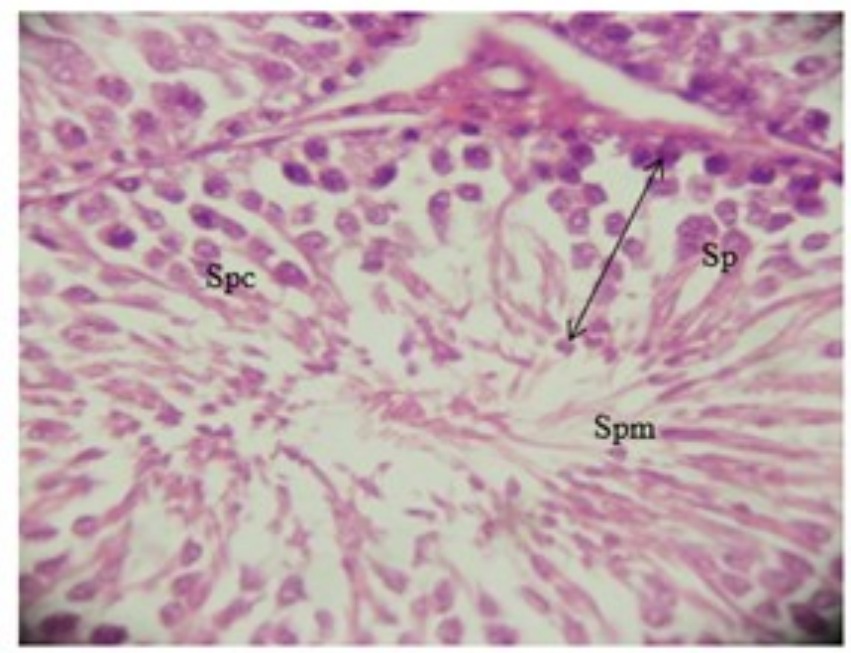

Figure 1: Transverse section of the rat testes (H\&Ex400), Group A(Control), dosed with $1 \mathrm{ml}$ distilled water daily. Showing normal seminiferous tubule with germ cells layers (spanned arrow) consisting of sertoli cells, spermatogonia cells (Sp), spermatocyte (Spc) with full maturation to the spermatids (Spm). The general architecture appears normal.
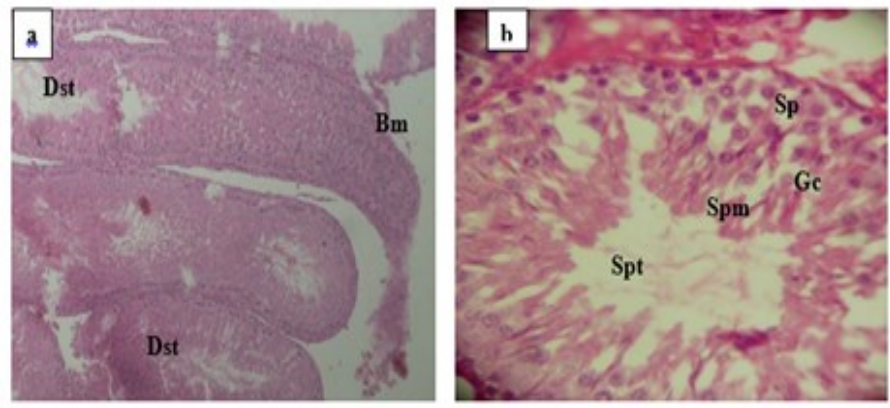

Figure 2: (a). Transverse section of the rat testes (H\&Ex100), Group $\mathrm{B}_{1}$ ( dosed with $0.04 \mathrm{mg} / \mathrm{kgbw}$ of $\mathrm{NO}_{2}$ ) daily for 60 days, showing distorted or deformed seminiferous tubule (Dst) with broken basement membrane (Bm). (b). Transverse section of the rat testes (H\&Ex40o), Group $\mathrm{B}_{2}$, (dosed with $0.04 \mathrm{mg} \mathrm{NO} \mathrm{N}_{2}+5.0 \mathrm{mg}$ testosterone). Showing a normal seminiferous tubule with normal germ cells layer (Gc) consisting normal sertoli cells, spermatogonia cells (Sp) with full maturation to the spermatids (Spm)/spermatozoa (Spt).
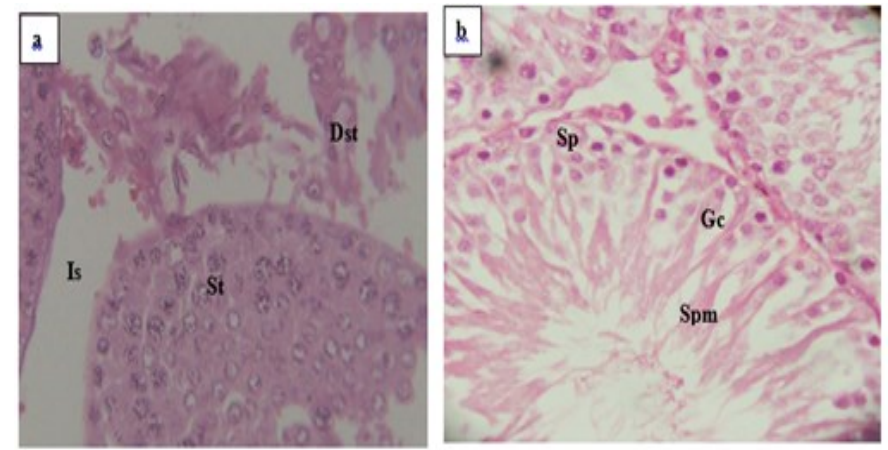

Figure 3: (a). Transverse section of the rat testes (H\&Ex40o), Group $\mathrm{C}_{1}$, (dosed with $0.06 \mathrm{mg} \mathrm{NO}_{2}$ ). Showing seminiferous tubules with abnormal shape (St), distorted region of tubules (Dst) and wide interstitial space (Is). (b). Transverse section of the rat testes (H\&Ex400), Group $\mathrm{C}_{2}$, (dosed with $0.06 \mathrm{mg} \mathrm{NO}+7.5 \mathrm{mg}$ testosterone). Showing seminiferous tubule with normal germ cell layers (Gc) consisting of sertoli cells, spermatogonia cells (Sp) with full maturation to the spermatids (Spm). 


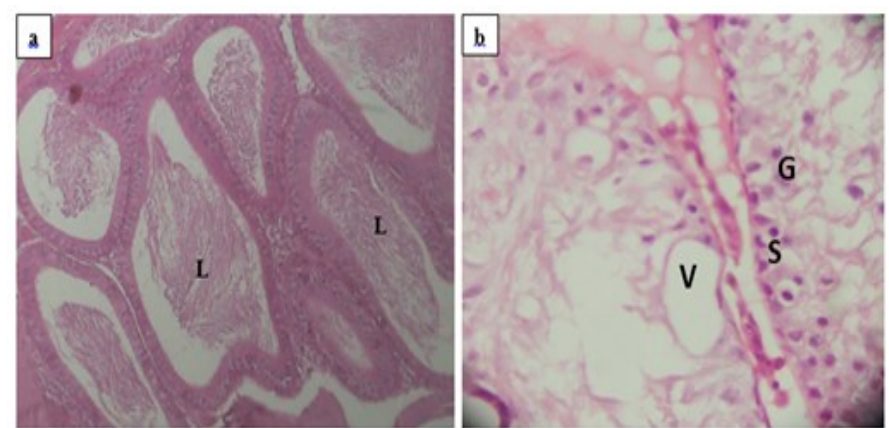

Figure 4: (a). Transverse section of the rat testes (H\&Ex40o), Group $\mathrm{D}_{1}$, (dosed with $0.08 \mathrm{mg} \mathrm{NO}_{2}$ ). Showing seminiferous tubule with deformed or irregular shape, wide lumen (L) without spermatogenesis, No germ cells. (b). Transverse section of the rat testes (H\&Ex400), Group $\mathrm{D}_{2}$, (dosed with $0.08 \mathrm{mg} \mathrm{NO} \mathrm{NO}_{2}+10.0 \mathrm{mg}$ testosterone). Showing seminiferous tubules with several vacuolations $(\mathrm{Vc})$, there is maturation arrest, while some show inadequate germinal cells.

\subsection{Analyses of Sperpm Parameters}

Gross observation of the testes after the administration of $\mathrm{NO}_{2}$ showed no apparent change in structure. The sperm counts reduced with increasing $\mathrm{NO}_{2}$ concentration, the reduction was statistically significant $(\mathrm{P}>0.05)$. In the $\mathrm{NO} 2 / \mathrm{T}$-treated rats, the sperm counts was significantly increased $(\mathrm{P}<0.05)$ (Table 1$)$. The number of sperm cells of the rats treated with $\mathrm{NO}_{2}$ was insignificantly decreased while the number of moveable sperm of $\mathrm{NO}_{2}$ /T-treated rats were found to be insignificantly increased ( $\mathrm{P}>0.05$ ) (Table 1). The normal morphology of sperm were found to be significantly $(\mathrm{P}<0.05)$ decreased in $\mathrm{NO} 2$-treated rats while that of $\mathrm{NO}_{2} / \mathrm{T}$-treated rats were slightly increased (Table 1).

Table 1: Effects of $\mathrm{NO}_{2}$ and Testoterone on Sperm Parameters

\begin{tabular}{|c|c|c|c|c|c|c|}
\hline \multirow[t]{2}{*}{ Group } & \multicolumn{2}{|c|}{$\begin{array}{l}\text { Mean Sperm } \\
\text { Counts } \\
\left(\mathrm{x10}^{6} \text { cells }\right)\end{array}$} & \multicolumn{2}{|c|}{$\begin{array}{l}\text { Normal } \\
\text { Sperm- } \\
\text { Morphology } \\
\text { (\%) }\end{array}$} & \multicolumn{2}{|c|}{$\begin{array}{l}\text { Motile - Sper- } \\
\text { matozoa } \\
\text { Grading (\%) }\end{array}$} \\
\hline & $\mathrm{NO}_{2}$ & $\begin{array}{l}\mathrm{NO}_{2} / \\
\text { Testo }\end{array}$ & $\mathrm{NO}_{2}$ & $\begin{array}{l}\mathrm{NO}_{2} / \\
\text { Testo }\end{array}$ & $\mathrm{NO}_{2}$ & $\begin{array}{l}\mathrm{NO}_{2} / \\
\text { Testo }\end{array}$ \\
\hline A & $14.0 \pm$ & 13.4 & 83.8 & 65.0 & 95.6 & 57.5 \\
\hline B & $07 \cdot 3^{ \pm}$ & 14.6 & 67.8 & 65.0 & 89.4 & 65.0 \\
\hline $\mathrm{C}$ & $05.4 \pm$ & 16.8 & 28.7 & 66.3 & 84.6 & 70.0 \\
\hline D & $\begin{array}{l}00.9 \pm \\
0.7^{*}\end{array}$ & $\begin{array}{l}15.4 \\
\pm 6.9\end{array}$ & $\begin{array}{l}23.2 \\
\pm 5.89^{*}\end{array}$ & $\begin{array}{l}68.8 \\
\pm 1.25\end{array}$ & $\begin{array}{l}84.6 \\
\pm 2.94\end{array}$ & $\begin{array}{l}75.0 \\
\pm 5.00\end{array}$ \\
\hline
\end{tabular}

${ }^{*} \mathrm{P} \leq 0.05$, otherwise $\mathrm{P} \geq 0.05$ when compared with the control, values are expressed as mean \pm SEM

\subsection{Testicular Oxidative Status}

The activities of Lipid peroxidation (MDA) were insignificantly $(\mathrm{P}>0.05)$ increased at $0.06 \mathrm{mg} / \mathrm{kgbw}$ and
$0.08 \mathrm{mg} / \mathrm{kgbw} \quad(0.059+0.005 \mu \mathrm{mol} / \mathrm{g}$ protein, $0.059+0.0110 \mu \mathrm{mol} / \mathrm{g}$ protein) higher than the dose of $0.04 \mathrm{mg} / \mathrm{kgbw}(0.050+0.005 \mu \mathrm{mol} / \mathrm{g}$ protein) and the

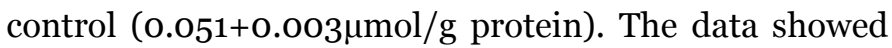
that the MDA level of the testicular $\mathrm{NO}_{2} / \mathrm{T}$-treated rats increased significantly $(\mathrm{P}<0.05)$ which showed an indication of increase lipid peroxidation caused by oxygen toxicity (Table 2). However, the activities of Super Oxide Dismutase (SOD) was significantly decreased in $\mathrm{NO}_{2}$ dosed-rats $(\mathrm{P}<0.05)$. Meanwhile, there was significant increased of testicular $\mathrm{SOD} \mathrm{NO}_{2} / \mathrm{T}$-dosed rats (table 2).

Table 2: Effects of $\mathrm{NO}_{2}$ and Testoterone on Oxidative Status of Rat Testes

\begin{tabular}{lllll}
\hline Group & $\begin{array}{l}\text { Mean Lipid peroxi- } \\
\text { dation (nm MDA/ } \\
\text { ml) } \pm \text { SEM }\end{array}$ & \multicolumn{2}{l}{$\begin{array}{l}\text { Superoxide Dismutase } \\
\text { (SOD) (U/L) } \pm \text { SEM }\end{array}$} \\
\hline \multirow{2}{*}{$\mathrm{NO}_{2}$} & $\begin{array}{l}\mathrm{NO}_{2} / \\
\mathrm{Testo}^{2}\end{array}$ & $\mathrm{NO}_{2}$ & $\mathrm{NO}_{2} /$ Testo \\
$\mathrm{A}$ & $0.051 \pm$ & 07.77 & 0.430 & 25.35 \\
& & & & \\
$\mathrm{~B}$ & 0.050 & 19.06 & 0.119 & 25.74 \\
& \pm 0.005 & $\pm 0.872^{*}$ & \pm 0.023 & $\pm 0.060^{*}$ \\
$\mathrm{C}$ & 0.059 & 16.09 & 0.112 & 25.60 \\
& \pm 0.011 & $\pm 0.851^{*}$ & $\pm 0.002^{*}$ & $\pm 0.090^{*}$ \\
$\mathrm{D}$ & 0.059 & 20.40 & 0.097 & 25.90 \\
& \pm 0.005 & $\pm 1.368^{*}$ & $\pm 0.011^{*}$ & $\pm 0.040^{*}$ \\
\hline
\end{tabular}

${ }^{*} \mathrm{P} \leq 0.05$, otherwise $\mathrm{P} \geq 0.05$ when compared with the control, values are expressed as mean \pm SEM

\section{4.o DISCUSSION}

The concentration of nitrite as high as the doses considered in this study with duration of 60 days produced hostile condition against the well-being of the sperm cells. Thus, the proportion of normal sperm morphology decreases with increase in the nitrite doses. A number of other authors $[18,19,20]$ have also shown that cellular metabolism of nitrite is mediated by Nitric Oxide (NO), an acid radical known for its role in pathophysiology which involves human reproduction. Excessive NO synthesis from nitrite could be an important factor contributing to the morphological changes in sperm cells [20].

The decreased proportion of motile sperm cells reported here appeared to support the work of [21] which asserted that high nitrite and nitrate concentrations hindered sperm motility. The body reacts to hypoxia with adaptive responses, such as relaxation of smooth muscle, angiogenesis and vasodilation, thus increasing blood supply to tissues, compensating for the lack of oxygen. The adaptive response to hypoxia also induces an increase in testicular temperature. Elevated temperature triggers apop- 
tosis in dividing cell population of the testis and a decreased output of maturing spermatids in rats [7]. It has also been shown to have an impact on male testicular functions such as reduction of testosterone level and disturbances of spermatogenesis [9]. The distorted seminiferous tubules without germ cells and abnormal shaped tubules in the present study was also evident in previous report of increase histologic lesions recorded in seminiferous tubules and epithelial lining of the testes among the tested rats with nitrite $[6,22]$.The absence of spermatogonia cells in the wide seminiferous lumen were similar to the study of Pant and Srivastava [23] that reported histopathology effect of potassium nitrate exposed to adult male mice testes via water intake.

Interestingly, Nitric Oxide (NO) has been linked to increase in lipid peroxidation; malondialdehyde (MDA) in both human varicocele patients [24] and rats with experimental varicocele. This implies a role for peroxinitrites in the oxidative stress of varicocele and specifically an increase in NO subsequent to eNOS overexpression, has been linked to germ GCA in a mouse model of cryptorchidism [5] . The present study revealed non-significant increase MDA in dose dependent manner when only $\mathrm{NO}_{2}$ was given to the rats. Also, significant increase MDA was recorded in $\mathrm{NO}_{2}$ /testosterone-dosed rats.

The activities of the oxidative markers indicated that the testicular cells were under oxidative challenges, this was evident in decreased SOD observed in the $\mathrm{NO}_{2}$-dosed rats which was an indication that dismutase superoxide (an agent of stress) is at work. However, the exogenous nitrite $\left(\mathrm{NO}_{2}\right)$ intake exceeding the WHO recommended dose should be avoided, and in a case of taken above recommended dose, hormonal therapy or antioxidants (vitamins) are recommended as free radical scavengers to stop the oxidation reaction of the oxidants $\left(\mathrm{NO}_{\mathrm{x}}\right)$. Meanwhile, in this study the significant increased SOD in the $\mathrm{NO}_{2}$ /testosterone treated testes showed that the oxidative stress that was observed in $\mathrm{NO}_{2}$-treated testes has probably been ameliorated. The significant increase superoxide dismutase (SOD) value with increased nitrite dose in the present study goes in similar way with the reported increased NO from a variety of stresses which decreases testosterone secretion. Also very large increases in NO and formation of peroxinitrites are associated with oxidative stress, which may override the effects of Hypoxia Inducible Factor (HIF)-1 $\alpha$ and inhibit testosterone production $[5,25]$.

In a survey by U.S., it was observed that approximately $25 \%$ have used exogenous testosterone to treat low testosterone levels associated with male infertility. Induction of spermatogenesis can be achieved in immature non human primates by the administration of very high doses of testosterone although, the number of spermatozoa in the ejaculate remained rather low. Studies have also shown that testosterone can initiate precocious puberty, maturation of the male gonad and spermatogenic process $[2,26]$. It was also observed that the reactive oxygen specie triggered by nitrite would generate oxidative stress and histological damages [27] and it has also been shown that hypobaric hypoxia caused by excess nitrite induces partially reversible quantitative changes such as decrease in semen volume, sperm count and sperm motility [11].

$\mathrm{NaNO}_{2}$ affects testis morphology, some weight indices and sperm count in mature rats and could compromise fertility in man and other mammals. In conclusion, exposure to the Nitrite $\left(\mathrm{NO}_{2}\right)$ can predispose testes to danger under the dosage been considered in this study. Meanwhile, testosterone can effectively reverse the destructive effects caused by the intake of nitrite $\left(\mathrm{NO}_{2}\right)$ at the considered doses. Efficacy of testosterone will be better appreciated when rats are exposed to reduced concentration of nitrite.

\section{Conflict of interest}

Authors declare that there is no conflict of interest

\section{Authors' Contributions}

WOA conceived and designed the study,collected data, contributed to the monitoring of the benchwork and performed manuscript revision. KTA and AA Performed data collection, contributed to data analysis and monitoring of the benchwork. KAO performed data analysis. All authors approved the final manuscript.

\section{Acknowledgement}

We thank Prof. Adekunle Bakare of the Department of Zoology, Faculty of Science, University of Ibadan, for his assistance during the preliminary stages of this work.

\section{References}

1. U. S. Department of Health and Human Services. Toxicology and Carcinogenesis Studies of Sodium Nitrite. Drinking Water Studies. urinary nitrate. Fd. Chem. Toxic., 2001; 22: 789.

2. Pavlova, E, Dimova, D. Petrova, E, Gluhcheva Y. And Atanassova N. Changes In Rat Testis And Sperm Count After Acute Treatment With Sodium Nitrite. Bas, Institute Of Experimental Morphology, Pathology And Anthropology With Museum, 2013; Bg - 1113 Sofi A, Bulgaria.

3. Nelson M.l. Pituitary Hormones And Growth Retardation In Rats Raised At Simulated High Altitude (380om). Environ Physiol Biochem; 1975; 5:273-282. 
4. W.H.O. Nitrate And Nitrite In Drinking Water. Background Document For Development Of W.H.O Guidelines For Drinking Water Quality, 2007.

5. Del Punta, K., Charreau, E. H., and Pignataro, O. P. Nitric oxide inhibits Leydig cell steroidogenesis. Endocrinology, 1996; 137, 5337-43.

6. Sarada Sks, Dipti P, Anju B, Pauline T, Kain Ak, Sairam M, Sharma Sk, Ilarazkigan G, Devendra K, Selvamerthy W., Antioxidant Effect Of Beta-Carotene On Hypoxia Induced Oxidative Stress In Male Albino Rats. J. Ethnophamacol, 2002; 79:149-153

7. Farias J G, Bustos-Obregion E, Orellana R, Bucarey Jl, Quiroz E, Reyes Jg. Effects Of Chronic Hypo Basic Hypoxia On Testis Histology And Round Spermatid Oxidative Metabolism. Andrologia, 2005a; 37:47-52.

8. Okumura A, Fuse H, Kawauchi Y, Mizuno I, Akashi T. Changes In Male Reproductive Function After High Altitude Mountaineering. High Ait Med Boil, 2003; 4:349-353.

9. Farias Jg; Bustos-Obregon E, Japia Pj, Gutierrez E, Zepeda A, Juantok C, Cruz G, Soto G, Benites J, Reyes Jg. Time Course Of Endrocrine Changes In The Hypophysis-Gonad Axis Induced By Hypobasic Hypoxia In Male Rats. J.Reprod. Dev., 2008; 54:18-21

10. Hartman, P.E. Review: putative mutagens and carcinogens in foods, nitrate/nitrite ingestion and gastric cancer mortality. Environ. Mutagen., 1983; 5; 111.

11. Gasco M, Rubio J, Chung A, Villegas L, Gonzales Gf. Effects Of High Altitude Exposure On Spermatogenesis And Epididymal Sperm Count In Male Rats. Andrologia. 2003;35:368-374.

12. Farias JG, Bustos-Obregón E, Reyes JG. Increase in testicular temperature and vascularization induced by hypobaric hypoxia in rats. J. Androl., 2005b; 26: 693-697.

13. Spralt Di, O'dea Ls, Schoenfeld D, Butler J, Rao Pn, Crowley Jr Wf. Neuroendocrine- Gonadal Axis In Frequent Sampling Of Lh, Fsh And Testosterone. Am J Physiol Endocrinol Metab. 1988; 254:658-666.

14. Ahmad Mahmood, Iftikhar Mahmood, Ruqaiya Hasan, Mansoor Ahmad. Effects of human chorionic gonadotropin (hCG) on pituitary prolactin (PRL) in the lizard, Uromastix hardwickii. Pakistan journal of pharmaceutical sciences. 2004; 08/17(2): 21-7.

15. Turek B., Hlavsova D., Tucek J., Waldman J. and Cerna J. The fate of nitrates and nitrites in the organism. IARC Sci. Publ., 1980; 31:625.

16. Swerdloff Rs, Wang C, Bhasin S. "Development In The Control Of Testosterone Function” Barllieress Chn Endocrinal ; Metab. 1992; 6(2); 451-83.

17. Harding S.M, Velotta Jp. "Comparing The Relative Amount Of Testosterone Required To Restore Sexual Arousal, Motivation And Performance In Male Rats”. Horm Behar. 2011; 59(5):666-73.

18. Benjamin, N. Nitrates in the human diet-good or bad? Ann Zootech. 2000; 49:207-216.

19. McKnight G.M., Duncan C.W., Leifert C., Golden M.H.N. Dietary nitrate in man friend or foe. Br J Nutr. 1999; 81; 349-358.

20. Rosselli, M., Keller, P.J. and Raghvendra, K.D. Role of nitric oxide in the biology, physiology and pathophysiology of reproduction. Hum. Reprod. Update, 1998; 4, 3-24.

21. Piotr Epler, Jaros aw Chyb, David E. Kime, Mirosawa Soko owska-Miko. The effects of Nitrites and Nitrates on Sperm Motility of common Carp in vitro. Arch. Polish Fisheries. 2000; 8:15-24.

22. Akintunde, O.W.; Igbigbi, P.S. and Olaniyan, L.W.B. Adverse Effects On Male Rat Testes And Sperm Parameters Of Orally Administered Nitrite. Intl. J. Dev. Med. Sci. 2010; 3 (1\&2): 27-35.

23. Pant N, Srivastava S.P. Testikular and spermatotoxic. Effect of nitrate in mice. Hum. Exp. Toxicol.; 2000; 21:37-41.

24. Romeo, Martin Knapp and Stephen Scoot. BJP. 2003; 188:547-553.

25. Kostic T, Andric S, Kovacevic R, Maric D. The involvement of nitric oxide in stress-impaired testicular steroidogenesis. Eur. J. Pharmacol. 1998; 346:267-273.

26. Gromoll M, Simoni M, Weinbauer G, Nieshlag E. 1998; Spermatogenesis- specific genes deleted in infertile men: DAZ/DAZH Clinical aspect and animal model. SpringerVerlag, Milan, Pp. 273-294. 